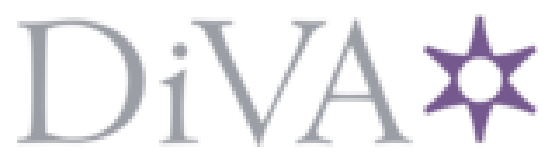

http://www.diva-portal.org

This is the published version of a paper published in Taxon.

Citation for the original published paper (version of record):

Rößler, R., Philippe, M., van Konijnenburg-van Cittert, H., McLoughlin, S., Sakala, J. et al. (2014)

Which name(s) should be used for Araucaria-likefossil wood? - Results of a poll.

Taxon

http://dx.doi.org/DOI 10.12705/631.7

Access to the published version may require subscription.

N.B. When citing this work, cite the original published paper.

Permanent link to this version:

http://urn.kb.se/resolve?urn=urn:nbn:se:nrm:diva-985 


\title{
Which name(s) should be used for Araucaria-like fossil wood?- Results of a poll
}

\author{
Ronny Rößler, ${ }^{1}$ Marc Philippe, ${ }^{2}$ Johanna H.A. van Konijnenburg-van Cittert, ${ }^{3,4}$ Stephen McLoughlin, ${ }^{5}$ \\ Jakub Sakala, ${ }^{6}$ Gea Zijlstra ${ }^{3}$ [co-ordinating authors] \& al. ${ }^{7}$ \\ 1 DAStietz, Museum für Naturkunde, 09111 Chemnitz, Germany \\ 2 UMR 5276 of the CNRS and Université Lyon 1, 69622 Villeurbanne, France \\ 3 Laboratory of Palaeobotany and Palynology, Budapestlaan 4, 3584 CD Utrecht, the Netherlands \\ 4 Naturalis Biodiversity Center, P.O. Box 2317, 2300 RA Leiden, the Netherlands \\ 5 Department of Paleobotany, Swedish Museum of Natural History, Box 50007, 10405 Stockholm, Sweden \\ 6 Charles University in Prague, Faculty of Science, Institute of Geology and Palaeontology, Albertov 6, 12843 Praha, Czech Republic \\ 7 for details of the 35 other authors, see end \\ Author for correspondence: Marc Philippe,philippe@univ-lyon1.fr \\ ORCID: R.R., 0000-0002-9692-2960
}

DOI http://dx.doi.org/10.12705/631.7

\begin{abstract}
Araucarioxylon Kraus is a widely known fossil-genus generally applied to woods similar to that of the extant Araucariaceae. However, since 1905, several researchers have pointed out that this name is an illegitimate junior nomenclatural synonym. At least four generic names are in current use for fossil wood of this type: Agathoxylon Hartig, Araucarioxylon, Dadoxylon Endl. and Dammaroxylon J.Schultze-Motel. This problem of inconsistent nomenclatural application is compounded by the fact that woods of this type represent a wide range of plants including basal pteridosperms, cordaitaleans, glossopterids, primitive conifers, and araucarian conifers, with a fossil record that extends from the Devonian to Holocene. Conservation of Araucarioxylon has been repeatedly suggested but never officially proposed. Since general use is a strong argument for conservation, a poll was conducted amongst fossil wood anatomists in order to canvass current and preferred usage. It was found that the community is divided, with about one-fifth recommending retention of the well-known Araucarioxylon, whereas the majority of others advocated use of the legitimate Agathoxylon. The arguments of the various colleagues who answered the poll are synthesized and discussed. There is clearly little support for conservation of Araucarioxylon. A secondary aspect of the poll tackled the issue as to whether Araucaria-like fossil woods should be either gathered into a unique fossil-genus, or whether two fossil-genera should be recognized, based on the respective presence or absence of axial parenchyma. A majority of colleagues favoured having one fossil-genus only. Agathoxylon can be used legitimately and appears to be the most appropriate name for such woods. However, its original diagnosis must be expanded if those woods lacking axial parenchyma are to be included.
\end{abstract}

Keywords Agathoxylon; Araucarioxylon; Dadoxylon; fossil wood; nomenclature

\section{INTRODUCTION}

Petrified woods are among the most common and popular fossils. Both public and private collections contain abundant specimens, ranging from small fragments to huge logs. Homoxylic woods dominate several collections, and wood similar to that of modern Araucariaceae (Araucaria, Agathis, Wollemia) is the most common group. Araucaria-like fossil wood (i.e., isolated pieces of secondary xylem with araucarian pitting on the radial faces of the tracheids and araucarioid crossfields, together with mostly uniseriate rays), unless it bears special features (e.g., resin canals, inflated axial parenchyma, or ray cell wall thickenings), has been given various names, including Agathoxylon Hartig, Araucarioxylon Kraus, Dadoxylon Endl., Dammaroxylon J.Schultze-Motel and, much more rarely, Colymboxylon Hartig, Araucarites C.Presl sensu Goeppert,
Ullmannites Tuzson, amongst others (Philippe, 1993). Numerous contributions have discussed the taxonomic, nomenclatural and systematic problems relating to these woods following the work of Gothan (1905) and continuing up until that of Zheng (2000) and Kurzawe \& Merlotti (2009, 2010).

Despite these debates, consensus has not been attained on the application of a name for such woods that is in accordance with the rules of the Melbourne Code (McNeill \& al., 2012). Most nomenclatural types are lost, or display a wood anatomy completely departing from that of Araucaria-like fossil wood as defined above. Most original generic diagnoses do not describe features which are nowadays considered crucial in fossil-wood determination. As stated once by an anonymous reviewer "every example of bad practice one could possibly imagine can be found somewhere in the literature on fossil wood".

Received: 13 Feb 2012 | returned for revision: 31 May 2013 | revision received: 23 Jun 2013 | accepted: 3 Nov. 2013 | published online ahead of inclusion in print and online issues: 27 Jan 2014 || C International Association for Plant Taxonomy (IAPT) 2014 
As a first step towards achieving a consistent and legitimate nomenclature for these woods to the satisfaction of all palaeobotanists/palaeoxylotomists interested in this topic, a poll was launched in November 2011, following a proposal by Ronny Rößler and subsequent discussion held in Budapest during the 8th European Palaeobotany and Palynology Conference (EPPC, held in 2010). More than 50 answers were received and they are analyzed here. In this paper, we review the nomenclature and taxonomy backgrounds related to Araucaria-like fossil woods, summarize the opinions of palaeobotanists and make firm recommendations for future nomenclature.

\section{NOMENCLATURE BACKGROUND}

Agathoxylon Hartig 1848 has been frequently used for Araucaria-like wood only in the past twenty years (Fig. 1). Following a nomenclatural review of such fossil woods, Philippe (1993) noted that Agathoxylon Hartig is legitimate, regularly used and was circumscribed by a diagnosis that permits inclusion of fossil species with Araucaria-like anatomy. That review consequently proposed that Agathoxylon be used for all such woods as it is the earliest name that can be applied unambiguously to fossil woods with Araucaria-like anatomy. This proposition has been variously accepted (e.g., Ottone \& Medina, 1995; Valenzuela \& al., 1998; Zamuner \& Falaschi, 2005; Poole \& Mirzaie Ataabadi, 2006; Salunkhe \& Yagayani, 2006; Crisafulli \& al., 2009; De Wit \& al., 2009; Gnaedinger \& Herbst, 2009; Vera \& Césari, 2012; Kustacher \& al., 2013), questioned (Falcon-Lang \& Cantrill, 2001) or ignored (e.g., Wang, 2000; Wang \& al., 2000; Ash, 2003; Morgans-Bell \& McIlroy, 2005; Noll \& al., 2005; Lucas \& al., 2010). The original type of Agathoxylon is probably lost; hence a neotype should be selected to support its continued use.

Araucarioxylon Kraus in Schimper 1870 has been used for Araucaria-like wood for more than a century. When Kraus published Araucarioxylon, however, he included four synonyms, the oldest of which is Pissadendron Endl. 1842. The two species originally included in Pissadendron by Endlicher are included in Araucarioxylon by Kraus with new combinations, together with an explicit statement that he considered Pissadendron to be fully included within Araucarioxylon. Similarly, Pissadendron is a superfluous substitute name for Pitys Witham 1833. Thus, Araucarioxylon and Pissadendron are illegitimate superfluous names typified by the type of Pitys (Art. 7.5). Pitys Witham (not to be confused with Pytys Endl. 1837) was originally spelled "Pitus" but the later spelling "Pitys" has been conserved (see Doweld \& Reveal, 2002; McNeill \& al., 2006: 419). The type of Pitys Witham is P. antiqua (misspelled "P. antique" in McNeill \& al. 2005: 419).

After Gothan (1905) treated it as a younger synonym of Dadoxylon, Araucarioxylon became much less used than the latter, until the 1970s, when it experienced a revival (Fig. 1). Only recently has Agathoxylon supplanted its position as the most favoured name for such woods.

Dadoxylon Endl. 1847 was extensively used for Araucarialike wood for more than a century, though that usage has partly been restricted to woods from Palaeozoic (CarboniferousPermian) occurrences. Philippe (1993), however, considered Dadoxylon to be an illegitimate, superfluous, synonym of Pinites Lindl. \& Hutton 1832. However, though Endlicher included Pinites (with references to the works of both Witham, 1833, and Lindley \& Hutton, 1832) as a synonym of Dadoxylon, he also (1847: 293) clearly excluded Pinites eggensis Lindl. $\&$ Hutton. Recently this species name has been taken as the type of Pinites. New investigations by Falcon-Lang (pers. comm.) of the publication dates of the fascicules of The fossil flora of Great-Britain (Lindley \& Hutton, 1832-1836) improved those given by Stafleu \& Cowan (1981: 54). Falcon-Lang found that $P$. eggensis was validly published in April 1832 (cf. Melbourne Code, Art. 31.3). The remaining three species of Pinites were not validly published in the first issue (dated July 1831) of The fossil flora of Great Britain (as three species are simultaneously published without a generic diagnosis). These conclusions indicate that Endlicher was using the name Pinites in a sense exclusive of its type and therefore, Dadoxylon should not be taken as an illegitimate superfluous renaming of Pinites.

The type of Dadoxylon has been problematic. In conflict with Art. 10.5(b) (McNeill \& al., 2012), Andrews (1955: 143) automatically selected the first species cited by Endlicher (1847: 34 ) as the type, namely D. withamii (三 Pinites withamii Lindl. \& Hutton 1833). Pinites withamii is a wood with multiseriate rays that today is usually assigned to Pitys Witham 1833. Andrew's (1955) choice is superseded by the designation
Fig. 1. Number of species described versus time for the genera Araucarioxylon (diamond and solid line), Dadoxylon (square and dashed line) and Agathoxylon (triangle and dotted line), updated from Philippe (2011). Note the reversal in the use of Araucarioxylon versus Dadoxylon in the 1970-1980 interval.

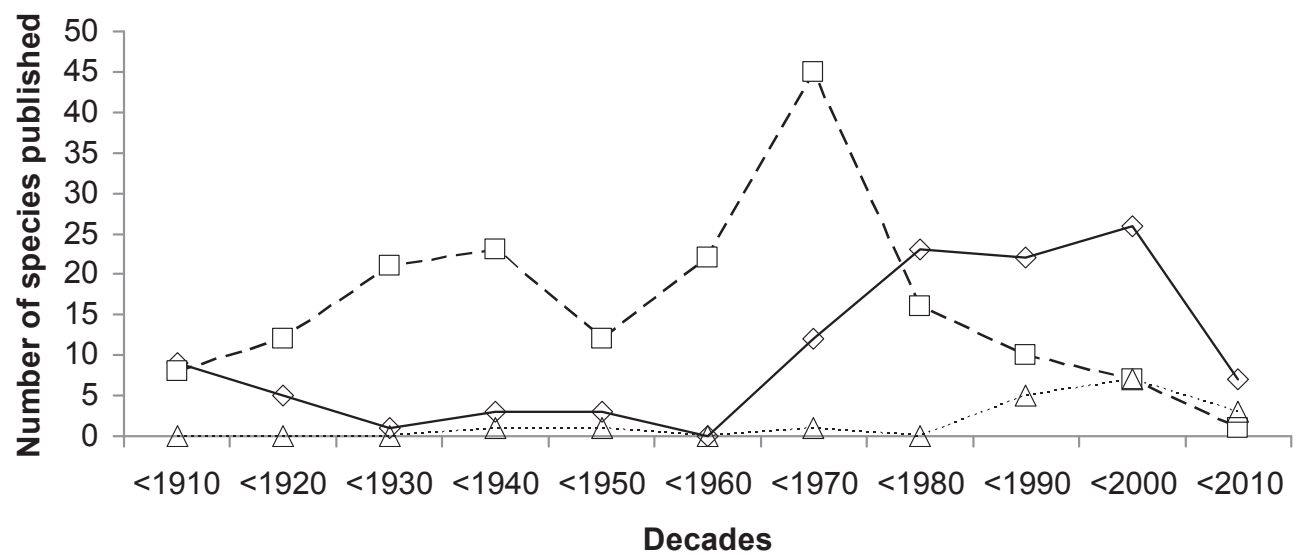

Version of Record (identical to print version). 
of Lepechina \& Jatsenko-Chmelevsky (1966: 68), D. brandlingii (三 Pinites brandlingii Lindl. \& Hutton ex Witham 1833). Andrews (1955: 212) also erroneously quoted $P$. brandlingii as the type of Pinites Lindl. \& Hutton 1832. Both Endlicher (1847: 298) and Lepechina \& Jatsenko-Chmelevsky (1966: 68) clearly included features of the pith, primary xylem and secondary xylem in their diagnosis of Dadoxylon. The secondary xylem of Pinites brandlingii has anatomical characters similar to those of modern Araucariaceae, but its age and primary structures suggest that it represents a cordaitalean.

Dammaroxylon J.Schultze-Motel 1966 (type: D. africanum J.Schultze-Motel 1966) is validly published and legitimate. However, its diagnosis includes "Randzellen" (literally "marginal cells"), the nature of which is unclear. Such features may represent genuine spaces flanking the rays or simply preservational artefacts caused by the dissolution of primary cell walls or the local accumulation of gases during decay, or shrinkage of cells during fossilisation. No one has yet advocated using Dammaroxylon for all Araucaria-like woods.

"Megadendron" Rchb. 1836 was used for a large trunk from the Early Permian of Chemnitz, found in 1751. One piece of this famous trunk is still available in the Senckenberg Natural History Collections in Dresden. Göppert (1865: 251) already treated this as a gymnosperm wood of the Araucaria-type (no description, only by placement in synonymy). Re-investigation by Noll $\&$ al. (2005: 30$)$ confirmed this. If it had been validly published, "Megadendron" could have been a taxonomic synonym of Araucarioxylon. However, "Megadendron" Rchb. was not validly published by Reichenbach (Leitfaden Königl. Sächs. Naturhist. Mus.: 6. 1836) or by Gutbier (in Geinitz \& Gutbier, Verstein. Perm. Form. Sachsen 2: 26. 1849) or Gothan (Abh. Königl. Preuss. Geol. Landesanst., n. F., 44: 14. 1905.) (see Farr \& Zijlstra, 1996-). Megadendron has since been validly published by Miers (in Trans. Linn. Soc. London, Bot. 1: 109, t. 15, fig. 1-8. 1875) for an extant taxon closely related to Barringtonia J.R.Forst. \& G.Forst.

\section{口TAXONOMY BACKGROUND}

Two main taxonomical problems compound the nomenclatural one. First, until Gothan's seminal work (1905), fossil wood with araucarian radial tracheid pitting was considered as Araucaria-like, regardless of the nature of its cross-field pitting, and of the ray seriation as well (Kraus, 1870). Most classifications before Kraus (1870) used features like growth-ring pattern or external appearance, features which are nowadays regarded as of little taxonomical value. Pre-1870 publications, however, established a most intricate web of taxonomical and nomenclatural synonymies (Kurzawe \& Merlotti, 2009, 2010). This is worsened by the facts that several types (specimens) are lost and that their descriptions often lack information about cross-fields.

A second issue is that no consensus has ever been reached as to whether one or two genera should be recognized for Araucaria-like fossil wood based on the presence or absence of axial parenchyma. Already in 1848, in its protologue, Agathoxylon Hartig is clearly intended for wood with axial parenchyma, as opposed to Colymboxylon Hartig and Trematoxylon Hartig, two names that have never been used, except by Hartig himself. Trematoxylon, said to have large fenestriform cross-field pits, is probably a synonym of Xenoxylon Gothan (Philippe \& Thévenard, 1996), whereas Colymboxylon has not been provided with a type. Despite extensive searching in Germany, we have not been able to locate the type of Agathoxylon cordaianum Hartig 1848. It is apparently lost (and a neotype will have to be designated) and it is impossible to be known if it had axial parenchyma (taphonomic artefacts are common in fossil wood). First-hand palaeoxylological experience reveals that it is difficult to confidently discount the absence of axial parenchyma in a fossil wood. Moreover, the occurrence of axial parenchyma is somewhat inconsistent in modern Araucariaceae, so the systematic value of this character is equivocal.

From a nomenclatural perspective it is not a problem to emend the diagnosis of Agathoxylon in order to include fossil wood both with and without axial parenchyma, and this was done by Philippe (1995). Nevertheless, should someone defend the taxonomical position that Araucaria-like fossil woods respectively with or without axial parenchyma be assigned to separate genera, Agathoxylon (pending an appropriate neotypification of $A$ cordaianum) would accommodate the first of these categories. Another name would be required for those woods lacking axial parenchyma, and Colymboxylon Hartig would be a logical choice, despite being minimally described and not provided with a type.

\section{- THE POLL ON ARAUCARIA-LIKE FOSSIL WOOD}

In November 2011, R. Rößler and M. Philippe sent a message and questionnaire to 74 colleagues potentially interested in this nomenclatural and taxonomic problem. Each was asked to forward the questionnaire to any further researchers wishing to provide an opinion. In this manner we consider the poll reached at least $90 \%$ of the active fossil wood anatomists.

The delivered message included a short summary of the nomenclature background, similar to the one provided above, and remembered that only three names have been in use for Araucaria-like fossil wood since now about a century: Agathoxylon, Araucarioxylon and Dadoxylon. Following the introduction, three alternative nomenclatural proposals were outlined. Researchers were asked to provide a recommendation for the most appropriate course of action. The proposals were presented as follows:
Among our community of paleoxylologists there is discussion about three possibilities to name isolated sec- ondary xylem pieces with an Araucaria-like anatomy:
1 - Use Araucarioxylon (in this case a proposal should be prepared for conservation and a type selected);
2 - Use Dadoxylon also for isolated secondary xylem;
3 - Use the validly published and legitimate Agathox- ylon Hartig (the type of which is apparently lost; a neotype should be selected).


Preliminary discussions highlighted this poll to be an opportunity to debate a related taxonomical choice, i.e., should one fossil-genus or two be recognized for Araucaria-like fossil wood, depending on the perceived significance of axial parenchyma. Thus, a second question was presented:

\section{Should two different fossil-genera be used for isolated Araucaria-like secondary xylem with or respectively without axial parenchyma? \\ $4-$ No; \\ 5 - Yes (then, please, indicate which names you recommend).}

Fifty-six answers were received (Table 1; Appendix 1). Five colleagues declared insufficient involvement to provide a meaningful opinion. Three others kindly shared their thoughts, but did not express any clear position. Several colleagues emphasized that they would prefer historical priority being ignored where a subsequent name has become well established and is clearly defined. Most answers also emphasized that it would be greatly beneficial to have this question settled definitively, in strict accordance with $I C N$ requirements, to avoid further nomenclature confusion. First, results about the taxonomy will be presented, then those about the nomenclature.

Thirty-seven colleagues expressed a position about the taxonomical point. It was often underlined that axial parenchyma being distributed with little consistency among the taxa or even the individuals of the extant Araucariaceae, this feature should not be accorded too much importance. In contrast, other colleagues considered the occurrence of axial parenchyma to be an important phylogenetic trait in conifer woods; at the same time pointing out, however, that axial parenchyma is rather inconsistent in modern Araucariaceae. Some emphasized that axial parenchyma, being a delicate tissue, is often poorly preserved, making it an unreliable feature for fossil wood identification.

The eight colleagues advocating the use of two taxa mostly suggested the use of Agathoxylon for woods with axial parenchyma and of Dadoxylon for those without ( $n=5$ persons). The others suggested various name pairings for woods respectively with and without axial parenchyma: Agathoxylon and Araucarioxylon, Araucarioxylon and Agathoxylon, and Araucarioxylon and Dadoxylon ( $n=1$ each).
With respect to the initial nomenclature question, ten responses recommended the use of Araucarioxylon as a general name for Araucaria-like woods, owing to it being a familiar and optimally informative name. It was also regularly asserted that Araucarioxylon is preferable in being not "as general" or "as widely encompassing" as Dadoxylon.

Even though Dadoxylon is now recognized to be legitimate, only seven contributors advocated use of this name. Respondents repeatedly alluded to Felix's (1886) policy, i.e., to use Dadoxylon for Palaeozoic woods and Araucarioxylon for Mesozoic and Cenozoic ones. Other contributors noted that such a policy is difficult to employ, since in the protologue most Araucarioxylon species are based on Palaeozoic material. Furthermore, geological age alone should not be used for taxonomical differentiation (Bateman \& Hilton, 2009).

Thirty-one replies (65\% of the 48 answers with a choice) recommended the use of Agathoxylon, mostly based on this being the first validly published and legitimate name that can be used unambiguously for isolated pieces of secondary xylem. Two responses emphasized that, should Agathoxylon be selected, this would necessitate numerous new combinations. However, one contributor noted that this should not be seen as a disadvantage, but rather an ideal opportunity to check all the published species and to transfer to Agathoxylon only those genuinely representing "Araucaria-like fossil woods" as defined here.

One respondent argued that, all names being problematic, the one selected should be that which has enjoyed most usage in the palaeobotanical community over the last 20 years. Two other colleagues underlined that, should the name Araucarioxylon be proposed for conservation against Pitys, and should this conservation be accepted, then Araucarioxylon would fall into taxonomical synonymy with Agathoxylon Hartig. One answer noted that Hartig (1848) also proposed Colymboxylon for Araucaria-like fossil wood (but without axial parenchyma), albeit that name has never been used subsequently and has no designated type.

Finally, it was also suggested that it might be possible to retain Araucarioxylon and Dadoxylon, not as names for welldefined plant fossil-genera, but as names for informal morphological groupings without any formal taxonomical status (such as "turmae" in palynology), for those fossil woods left in open nomenclature.

Table 1. Poll summary for the 56 answers received. Q1 = How "to name isolated secondary xylem pieces with an Araucaria-like anatomy." Q2 = "Should two different fossil-genera be used for isolated Araucarialike secondary xylem with or respectively without axial parenchyma?" If the answer to Q2 was "yes" it was asked to "indicate which names you recommend". Answers are given here with their respective score, the name recommended for wood with axial parenchyma first.

no answer Araucarioxylon Dadoxylon Agathoxylon

Q1

no answer

Q2

19 one genus

29 two genera

Agathoxylon/Dadoxylon (5)

Agathoxylon/Araucarioxylon (2)

Araucarioxylon/Dadoxylon (1) 


\section{口 POLL DISCUSSION}

Gothan (1905) was probably the first to discuss the naming of Araucaria-like fossil woods according to rules similar to modern criteria. Significantly, his contribution was published at about the same time as the first edition of the code of nomenclature (Briquet, 1906). Gothan selected Dadoxylon for Araucaria-like fossil woods, and was followed by most authors until about 1970-1980, after which, for various reasons, most authors preferred Araucarioxylon (Fig. 1). From the current poll it is clear that few specialists favour the continued use of Dadoxylon for isolated secondary xylem pieces.

The fact that many different species of fossil wood have been assigned to Dadoxylon, despite their large taxonomical diversity, is clearly seen as an impediment to retain this generic name. Indeed the botanical affinity of the woods in question is variable. Palaeozoic (Carboniferous-Permian) Araucarialike woods commonly occur in biological attachment to axes with septate piths and a primary vasculature suggestive of cordaitaleans (Gothan, 1905), although others may represent pteridosperms (Galtier \& Scott, 1994) or ullmannian (Lemoigne \& Schaarschmidt, 1968) or walchian (Lemoigne \& Tyroff, 1967; Noll \& al., 2005) conifers. In contrast, most Late Cretaceous-Holocene woods of this type are undoubtedly coniferous, and should almost certainly be placed within the extant Araucariaceae. The affinity of other woods of late Palaeozoic and early Mesozoic age is less certain and may represent a range of conifers, pteridosperms and other extinct gymnosperms (e.g., Pigg \& Trivett, 1994). One might even consider proposing the conservation of Cordaixylon Grand'Eury 1877, a younger synonym, for the Palaeozoic woods. These cannot, however, be segregated from non-cordaitalean woods on the basis of the anatomy of their secondary xylem alone.

The main reason mentioned for the use of Araucarioxylon is overwhelmingly that it is familiar. Indeed, Araucarioxylon is used in every textbook and adorns labels in most fossil shops, in every palaeontological museum and in countless popular media outlets (web-sites, field guides, magazines and so forth). Araucarioxylon is also widely employed in the scientific literature, although it is rarely indicated to be an illegitimate superfluous synonym. An analysis of new specific names published for Araucaria-like fossil woods between 1900 and 2010 reveals that the name Araucarioxylon was rarely used before 1972, became more frequently used than Dadoxylon in the 1980s, and then sharply decreased in usage (first relatively and then absolutely and relatively, Fig. 1). An illustration of this astonishing evolution of nomenclature is exemplified by Trivedi \& Srivastava (1990) who published four new combinations in Araucarioxylon, even though this name had already been stated to be a junior synonym, in the same journal (Vogellehner, 1964, who treated it as a synonym of Dadoxylon). It is noteworthy that few of the respondents who supported the use of Araucarioxylon have actually published material under this name.

In contrast, answers advocating the use of Agathoxylon put forward respect to the Code and the obligation to use legitimate names as their guiding principles for the choice of a genus name. It is acknowledged that employment of this name would require numerous new combinations to be coined, although this could also be an opportunity to clarify the character sets of the numerous species described previously. It is clear that among the approximately 440 fossil species described as Araucaria-like secondary xylem, only around half fit the precise definition of this group given above. Further, the synonymy rate among this half is apparently high to very high (Philippe, 2011). The reasons advocated to avoid the use of Agathoxylon were mostly that it is not commonly employed, which is true with respect to the general public and even among several colleagues, but incorrect when species described between 1990 and 2010 are considered. It is true that during the last decade equivalent numbers of new species have been ascribed to Araucarioxylon and Agathoxylon (Table 2), but if the number of published new combinations is taken into account, then Agathoxylon greatly outnumbers Araucarioxylon.

Table 2. Species of Araucaria-like fossil wood newly described during this century (2001-2012).

\begin{tabular}{llllll}
\hline Year & Genus & Species & Reference & Age & Locality \\
\hline 2001 & Araucarioxylon & agashii & Narayanaswamy, 2001 & Permian & India \\
2001 & Araucarioxylon & chapmannae & Poole \& Cantrill, 2001 & Cretaceous & Antarctica \\
2001 & Agathoxylon & ramanujamii & Narayanaswamy, 2001 & Permian & India \\
2002 & Dadoxylon & byeongpungense & Kim \& al., 2002 & Cretaceous & Korea \\
2002 & Agathoxylon & liguaensis & Torres \& Philippe, 2002 & Jurassic & Chile \\
2002 & Dadoxylon & transylvanicum & Iamandei \& al., 2002 & Permian & Romania \\
2002 & Araucarioxylon & xinchangense & Duan \& al., 2002 & Cretaceous & China \\
2004 & Dammaroxylon & formosum & Iamandei \& Iamandei, 2004 & Cretaceous & Romania \\
2004 & Agathoxylon & ultimus & Iamandei \& Iamandei, 2004 & Cretaceous & Romania \\
2005 & Agathoxylon & matildense & Zamuner \& Falaschi, 2005 & Jurassic & Argentina \\
2007 & Araucarioxylon & tohegaoense & Agarwal \& al., 2007 & Permian & India \\
2011 & Agathoxylon & togeumense & Oh \& al., 2011 & Cretaceous & Korea \\
2011 & Agathoxylon & lamaibandianus & Crisafulli \& Herbst, 2011 & Triassic & Argentina \\
\hline
\end{tabular}


A proposal to conserve Araucarioxylon would need to address several issues: Dadoxylon has been used as frequently as Araucarioxylon for naming tracheidoxyls (isolated fragments of pycnoxylic homoxylous secondary xylem); Araucarioxylon is automatically typified by the Pitys type, which is very different to that usually assigned to Araucarioxylon; Araucarioxylon has been inconsistently used, even in recent times (Philippe, 2011); and there is no consensus about its application (this poll). These facts suggest that conservation of Araucarioxylon should not be pursued.

\section{CONCLUSIONS}

A recurrent opinion expressed in responses to the questionnaire was the strong desire to achieve general agreement about the naming of Araucaria-like fossil wood. This poll did yield a clear consensus. Although a few people, based on valid reasons, advocated the use of Dadoxylon or Araucarioxylon, a much larger number recommended the use of Agathoxylon. The survey clearly indicates that there is no general agreement to conserve Araucarioxylon. Furthermore, conservation of the latter would be difficult to advocate given the complex nomenclatural changes required and the lack of unanimous support.

In the community of fossil wood anatomists, the prevailing view is that only one genus name is necessary for Araucaria-like fossil woods, with or without axial parenchyma, and that this name should be Agathoxylon. Its type is provided by the only original species name: A. cordaianum. Unsuccessful searches for the holotype of this species suggest that Hartig's original material has been lost. This necessitates the designation of a neotype. Hartig's generic characters are clear from his key on pp. 189-190. Since he recognized only one species, its name is validly published. From the brief species diagnosis on p. 188, however, it is not yet clear which subsequently established species may be synonyms. This matter should be resolved in a future publication, together with combinations under Agathoxylon of many species that in the past have been attributed to Araucarioxylon and/or Dadoxylon.

Several respondents to the poll concluded their comments by stating that naming is not a goal in itself, and that the nomenclatural problem should not obscure the value that fossil woods embody for palaeobiological, palaeoecological and palaeobiogeographical analyses.

\section{口 ACKNOWLEDGMENTS}

The authors are grateful to all their colleagues who kindly answered, whether they contributed to the poll or not, and to Editors John McNeill, Gerry Moore and Franz Stadler. Thanks are due also to Howard Falcon-Lang about the publication dates of The Fossil Flora of Great-Britain, to Michael Krings for information about Hopfgarten, the type-locality for Agathoxylon, and to Eckhard Mönnig, Ralf Werneburg, Gerd-Rainer Riedel, Norbert Hauschke, Stephan Schultka and Volker Wilde for information about collections in their care. Five anonymous reviewers kindly helped to improve a first version of this paper. This research got support from National Natural Science Foundation of China (41172006).

\section{- LIST OF OTHER AUTHORS}

Marion Bamford, Bernard Price Institute for Palaeontological Research, University of the Witwatersrand, P. Bag 3, WITS 2050, Johannesburg, South Africa

Menno Booi, Netherlands Centre for Biodiversity Naturalis, P.O. Box 9517, 2300 RA Leiden, The Netherlands

Mariana Brea, Laboratorio de Palebotánica, Centro de Investigaciones Científicas, CICYTTP-CONICET, Dr. Materi y España s/n, Diamante E3105BWA, Argentina ORCID: 0000-0002-8109-5595

Alexandra Crisafulli, UNNE - CECOAL - Área Paleontología CONICET, Casilla de Correo 128, W3400 Corrientes, Argentina

Anne-Laure Decombeix, CNRS - UMR AMAP, Bd de la Lironde, 34398 Montpellier, France ORCID: 0000-0002-6348-0086

Martina Dolezych, Senckenberg Naturhistorische Sammlungen, Königsbrücker Landstr. 159, 01109 Dresden, Germany

Tânia Dutra, Graduation Program in Geology, Universidade do Vale do Rio dos Sinos, Av. Unisinos, 950, 93022-000 São Leopoldo, RS, Brazil

Luis G. Esteban, Universidad Politécnica de Madrid, Departamento de Ingeniería Forestal, Ciudad Universitaria s/n, 28040 Madrid, Spain

Paula Falaschi, División Paleobotánica, Museo de Ciencias Naturales, Paseo del Bosque s/n, La Plata B1900FWA, Argentina

Zhuo Feng, Yunnan Key Laboratory for Palaeobiology, Yunnan University, Kunming 650091, P.R. China ORCID: 0000-0001-9635-1144

Silvia Gnaedinger, CECOAL-CONICET, RUTA 5, Km 2,5 CP 3400, Corrientes Argentina

Margot Guerra Sommer, Universidade Federal do Rio Grande do Sul (UFRGS), Programa de Pós-Graduação em Geociências, Av. Bento Gonçalves, 9500 prédio 43127 sala 201 Cx.P. 15001, 91501-970 Porto Alegre, RS Brasil

Melise Harland, GETECH, Kitson House, Elmete Hall, Elmete Lane, Leeds LS8 2LJ, U.K.

Rafael Herbst, CECOAL-CONICET, RUTA 5, Km 2,5 3400 Corrientes, Argentina

Eugenia Iamandei and Stãnilã Iamandei, Geological Institute of Romania, 1 Caransebeş Street, 012271 Bucharest, Romania

Hongen Jiang, Department of scientific History and Archaeometry, Graduate University of Chinese Academy of Sciences, Yuquan Rd. 19(A), Beijing 100049, P.R. China

Lutz Kunzmann, Senckenberg Natural History Collections Dresden, Königsbrücker Landstraße 159, 01109 Dresden, Germany

Francine Kurzawe, Curso de Pós-Graduação em Geociências, Instituto de Geociências, Universidade Federal do Rio Grande do Sul, Av. Bento Gonçalves, 9500, 91509-900 Porto Alegre, Brazil

Sheila Merlotti, Departamento de Botânica, Centro de Ciências Biológicas, Universidade Federal de Santa Catarina, Campus Universitário, Trindade, 88040-900 Florianópolis, Brazil

Serge Naugolnykh, Geological Institute of Russian Academy of Sciences, Pyzhevsky per. 7, 119017 Moscow, Russia

Harufumi Nishida, Faculty of Science and Engineering, Chuo University, 1-13-27 Kasuga, Bunkyo, Tokyo 112-8551, Japan

Robert Noll, In den Birkengärten 30, 67311 Tiefenthal, Germany

Changhwan Oh, Department of Biological Sciences, Chonbuk National University, 664-14 1Ga Deokjin-dong, Jeonju, 561-756, Republic of Korea 
Olga Orlova, Department of Paleontology, Geological Faculty, Moscow State University, Vorobjevy Gory, 119991 Moscow, Russia

Paloma de Palacios de Palacios, Universidad Politécnica de Madrid, Departamento de Ingeniería Forestal, Ciudad Universitaria s/n, 28040 Madrid, Spain

Imogen Poole, Department of Geology \& Petroleum Geology, King's College, University of Aberdeen, Aberdeen AB24 3UE, Scotland, U.K.

Roberto R. Pujana, Museo Argentino de Ciencias Naturales, Av. Ángel Gallardo 470, C1405DJR Buenos Aires, Argentina

Annamraju Rajanikanth, Birbal Sahni Institute of Palaeobotany, 53 University Road, Lucknow 226 007, India

Patricia Ryberg, University of Kansas, 1200 Sunnyside Ave., Lawrence, Kansas 66045, U.S.A.

Kazuo Terada, Fukui Prefectural Dinosaur Museum, 51-11 Terao, Muroko, Katsuyama, Fukui 911-8601, Japan

Frédéric Thévenard, UMR 5276 of the CNRS and Université Lyon 1, 69622 Villeurbanne, France

Teresa Torres, Departamento de Producción Agrícola, Facultad de Ciencias Agronómicas, Universidad de Chile, Correo 1004, Santiago, Chile

Ezequiel Vera, Museo Argentino de Ciencias Naturales, Av. Ángel Gallardo 470, C1405DJR Buenos Aires, Argentina

Wu Zhang and Shaolin Zheng, Shenyang Center of Geological Survey, China Geological Survey, Shenyang 110034, P.R. China

\section{口 LITERATURE CITED}

Agarwal, A., Tewari, R. \& Rajanikanth, A. 2007. A gymnospermous (Araucariaceae) wood from the Kamthi Formation, Wardha Valley Coalfield. Gondwana Geol. Mag. 22: 103-107.

Andrews, H.N., Jr. 1955. Index of generic names of fossil plants, 1820-1950. Bull. U.S. Geol. Surv. 1013: 1-262.

Ash, S. 2003. The Wolverine Petrified Forest, Utah. Utah Geol. Surv., Surv. Notes 35: 2-6.

Bateman, R.M. \& Hilton, J. 2009. Palaeobotanical systematics for the phylogenetic age: Applying organ-species, form-species and phylogenetic species concepts in a framework of reconstructed fossil and extant whole-plants. Taxon 58: 1254-1280.

Briquet, J. 1906. Règles internationales de la nomenclature botanique adoptées par le Congrès International de Botanique de Vienne 1905. Jena: Fischer.

Crisafulli, A. \& Herbst, R. 2011. La flora triásica del grupo El Tranquilo, provincia de Santa Cruz (Patagonia): Leños fósiles. Ameghiniana 48: 275-288. http://dx.doi.org/10.5710/AMGH.v48i3(310)

Crisafulli, A., Herbst, R. \& Stortti, L.M. 2009. Maderas gimnospérmicas de la Formación Tres Islas (Pérmico Inferior) de Uruguay. Gaea 5: 1-14. http://dx.doi.org/10.4013/gaea.2009.51.01

De Wit, M.C.J., Ward, J.D., Bamford, M.K. \& Roberts, M.J. 2009. The significance of the Cretaceous diamondiferous gravel deposits at Mahura Muthla, Northern Cape Province, South Africa. S. African J. Geol. 112: 89-108. http://dx.doi.org/10.2113/gssajg.112.2.89

Doweld, A.B. \& Reveal, J.L. 2002. Proposal to conserve the name Pitys Witham (Fossil Plants) with that spelling. Taxon: 51: 583-584. http://dx.doi.org/10.2307/1554886

Duan, S.-Y., Dong, C.-W., Pan, J. \& Zhu, G.-Q. 2002. Study on the fossil woods found in Xinchang, Zhejiang Province, China. Chin. Bull. Bot. 19: 78-86. [in Chinese with English abstract]

Endlicher, S. 1847. Synopsis coniferarum. St. Gallen, Switzerland: Scheitlin \& Zollikofer. http://dx.doi.org/10.5962/bhl.title.15336

Falcon-Lang, H.J. \& Cantrill, D.J. 2001. Gymnosperm woods from the Cretaceous (Mid-Aptian) Cerro Negro Formation, Byers Peninsula, Livingston Island, Antarctica: The arborescent vegetation of a volcanic arc. Cretaceous Res. 22: 277-293. http://dx.doi.org/10.1006/cres.2001.0259
Farr, E.R. \& Zijlstra, G. (eds.) 1996-. Index Nominum Genericorum (Plantarum). http://botany.si.edu/ing/ (accessed Jan 2012).

Felix, J. 1886. Untersuchungen über fossile Hölzer, II Stück. Z. Deutsch. Geol. Ges. 38: 483-492.

Galtier, J. \& Scott, A. 1994. Arborescent gymnosperms from the Visean of East Kirkton, West Lothian, Scotland. Trans. Roy. Soc. Edinburgh, Earth Sci. 84: 261-266. http://dx.doi.org/10.1017/S0263593300006076

Gnaedinger, S. \& Herbst, R. 2009. Primer registro de maderas gimnospérmicas de la Formación Roca Blanca (Jurásico Inferior), provincia de Santa Cruz, Argentina. Ameghiniana 46: 59-71.

Göppert, H.R. 1865. Die fossile Flora der Permischen Formation. Palaeontographica 12: 1-316.

Gothan, W. 1905. Zur Anatomie lebender und fossiler GymnospermenHölzer. Abh. Königl. Preuss. Geol. Landesanst., n.F., 44: 1-108.

Hartig, T. 1848. Beiträge zur Geschichte der Pflanzen und zur Kenntnis der norddeutschen Braunkohlen-Flora. Bot. Zeitung (Berlin) 6: 122-128, 137-141, 166-172, 185-190.

Iamandei, E. \& Iamandei, S. 2004. New conifers in Upper Cretaceous lignoflora from the South Apuseni. Acta Paleontol. Romaniae 4: $137-150$.

Iamandei, E., Iamandei, S. \& Dragastan, O. 2002. A Permian coniferous wood from the Arieseni, Tapu Mts.--Northern Apuseni Mts. Stud. Cercet. Geol. 47: 65-76.

Kim, K., Jeong, E.K., Suzuki, M., Huh, M. \& Paik, I.S. 2002. Some coniferous fossil woods from the Cretaceous of Korea. Geosci. J. 6: 131-140. http://dx.doi.org/10.1007/BF03028284

Kraus, G. 1870. Bois fossiles de conifères. Pp. 363-385 in: Schimper, W.P. (ed.), Traité de paléontologie végétale, tome 2. Strasbourg: Baillère.

Kurzawe, F. \& Merlotti, S. 2009. O complexo Dadoxylon-Araucarioxylon, Carbonífero e Permiano do Gondwana: Estudo taxonômico do gênero Dadoxylon. Pesq. Geoci. 36(2): 223-232.

Kurzawe, F. \& Merlotti, S. 2010. O complexo Dadoxylon-Araucarioxylon, Carbonífero e Permiano do Gondwana: Estudo taxonômico do gênero Araucarioxylon. Pesq. Geoci. 37(1): 41-50.

Kustatscher, E., Falcon-Lang, H. \& Lukeneder, A. 2013. Early Cretaceous araucarian driftwood from hemipelagic sediments of the Puez area, South Tyrol, Italy. Cretaceous Res. 41: 270-276. http://dx.doi.org/10.1016/j.cretres.2013.01.002

Lemoigne, Y. \& Schaarschmidt, F. 1968. Caractères anatomiques du bois d'Ullmannia bronni Göppert d'après des échantillons d'axes feuillés provenant du Permien d'Allemagne. Compt. Rend. Hebd. Séances Acad. Sci., Sér. D. 266: 87-877.

Lemoigne, Y. \& Tyroff, H. 1967. Caractères anatomiques d'un fragment de bois appartenant à l'espèce Walchia piniformis du Permien d'Allemagne. Compt. Rend. Hebd. Séances Acad. Sci., Sér. D. 265: 595-597.

Lepechina, V.G. \& Jatsenko-Chmelevsky, A.A. 1966. Classification and nomenclature of woods of Palaeozoic pycnoxylic plants. Taxon 15: 66-70. http://dx.doi.org/10.2307/1217590

Lindley, J. \& $\overline{\text { Hutton, W. 1832. The fossil flora }}$ of Great Britain; or, Figures and descriptions of the vegetable remains found in a fossil state in this country, vol. 1, part 1. London: Ridgway.

Lucas, S.G., Minter, N.J. \& Hunt, A.P. 2010. Re-evaluation of alleged bees' nests from the Upper Triassic of Arizona. Palaeogeogr. Palaeoclimatol. Palaeoecol. 286: 194-201. http://dx.doi.org/10.1016/j.palaeo.2010.01.010

McNeill, J., Barrie, F.R., Burdet, H.M., Demoulin, V., Hawksworth, D.L., Marhold, K., Nicolson, D.H., Prado, J., Silva, P.C., Skog, J.E., Wiersema, J.H. \& Turland, N.J. (eds.) 2006. International Code of Botanical Nomenclature (Vienna Code): Adopted by the Seventeenth International Botanical Congress Vienna, Austria, July 2005. Regnum Vegetabile 146. Ruggell: Gantner.

McNeill, J., Barrie, F.R., Buck, W.R., Demoulin, V., Greuter, W., Hawksworth, D.L., Herendeen, P.S., Knapp, S., Marhold, K., Prado, J., Prud'homme van Reine, W.F., Smith, G.F., 
Wiersema, J.H. \& Turland, N.J. (eds.) 2012. International Code of Nomenclature for algae, fungi, and plants (Melbourne Code): Adopted by the Eighteenth International Botanical Congress Melbourne, Australia, July 2011. Regnum Vegetabile 154. Königstein: Koeltz Scientific Books.

Morgans-Bell, H. \& McIlroy, D. 2005. Palaeoclimatic implications of Middle Jurassic (Bajocian) coniferous wood from the Neuquén Basin, west-central Argentina. Special Publ. Geol. Soc. London 252: 267-278. http://dx.doi.org/10.1144/GSL.SP.2005.252.01.13

Narayanaswamy, K. 2001. Studies on megafossils occurring in Lower Gondwana strata from Chandrapur District of Maharastra State. Thesis, Bangalore University, Bangalore, India.

Noll, R., Rößler, R. \& Wilde, V. 2005. 150 Jahre Dadoxylon-Zur Anatomie fossiler Koniferen- und Cordaitenhölzer aus dem Rotliegend des euramerischen Florengebietes. Veröff. Mus. Naturk. Chemnitz 28: 29-48.

Oh, C., Kim, K., Paik, I.-S. \& Lim, J.-D. 2011. Cretaceous conifer woods of Korea: Occurrences and palaeobiological implications. Rev. Palaeobot. Palynol. 164: 67-83. http://dx.doi.org/10.1016/j.revpalbo.2010.11.007

Ottone, E.G. \& Medina, F.A. 1995. A wood from the Early Cretaceous of James Ross Island, Antarctica. Ameghiniana 35: 291-298.

Philippe, M. 1993. Nomenclature générique des trachéidoxyles mésozoïques à champs araucarioïdes. Taxon 42: 74-80. http://dx.doi.org/10.2307/1223305

Philippe, M. 1995. Bois fossiles du Jurassique de Franche-Comté (NEFrance). Palaeontographica, Abt. B, Paläophytol. 236: 45-103.

Philippe, M. 2011. How many species of Araucarioxylon? Compt. Rend. Palevol 10: 201-208. http://dx.doi.org/10.1016/j.crpv.2010.10.010

Philippe, M. \& Thévenard, F. 1996. Repartition and palaeoecology of the Mesozoic wood genus Xenoxylon: Palaeoclimatological implications for the Jurassic of Western Europe. Rev. Palaeobot. Palynol. 91: 353-370. http://dx.doi.org/10.1016/0034-6667(95)00067-4

Pigg, K.B. \& Trivett, M.L. 1994. Evolution of the glossopterid gymnosperms from Permian Gondwana. J. Pl. Res. 107: 461-477. http://dx.doi.org/10.1007/BF02344068

Poole, I. \& Cantrill, D.J. 2001. Fossil woods from Williams Point Beds, Livingston Island, Antarctica: A Late Cretaceous southern high latitude flora. Palaeontology 44: 1081-1112. http://dx.doi.org/10.1111/1475-4983.00216

Poole, I. \& Mirzaie Ataabadi, M. 2006. Conifer woods of the
Middle Jurassic Hodjek Formation (Kerman Basin) Central Iran. I. A. W. A. J. 26: 489-505.

Salunkhe, V.S. \& Yagyani, B.A. 2006. A new species of fossil gymnospermous wood Agathoxylon Hartig from Uttatur, Tamil Nadu. Advances Pl. Sci. 19: 675-678.

Stafleu, F.A. \& Cowan, R.S. 1981. Taxonomic literature, ed. 2, vol. 3. Regnum Vegetabile 105. Utrecht: Bohn, Scheltema \& Holkema; The Hague: dr. W. Junk. http://dx.doi.org/10.5962/bhl.title.48631

Torres, T. \& Philippe, M. $2 \overline{002}$. Nuevas especies de Agathoxylon y Baieroxylon del Liásico de La Ligua, Chile, y evaluación de antecedentes paleoxilológicos en el Jurásico de America del Sur. Revista Geol. Chile 29: 3-19.

Trivedi, B.S. \& Srivastava, R. 1990. Nomenclatural note on some new combinations in Araucarioxylon Kraus and Podocarpoxylon Gothan (fossils). Taxon 39: 658-659. http://dx.doi.org/10.2307/1223385

Valenzuela, M., Diaz Gonzalez, T.E., Guttierez Villarias, M.I. \& Suarez de Centi, C. 1998. La Fm. Lastres del Kimmeridgiense de Asturias: Sedimentología y estudio paleobotánico inicial. Cuad. Geol. Ibér. 24: 141-171.

Vera, E.I. \& Césari, S.N. 2012. Fossil woods (Coniferales) from the Baqueró Group (Aptian), Santa Cruz Province, Argentina. Anais Acad. Brasil. Ci. 84: 617-626.

Vogellehner, D. 1964. Zur Nomenklatur der fossilen Holzgattung Dadoxylon Endlicher 1847. Taxon 13: 233-237. http://dx.doi.org/10.2307/1216692

Wang, J. 2000. Permian wood from Inner Mongolia, North China: With special reference to Palaeozoic climate change of north China Block. Palaeobotanist 49: 353-370.

Wang, S.J., Hu, Y.F. \& Cui, J.Z. 2000. A new species of Araucarioxylon Kraus from the early Early Permian, Nei Mongol, China. Acta Bot. Sin. 42(4): 427-432.

Witham, T.M. 1833. The internal structure of fossil vegetables found in the Carboniferous and Oolitic deposits of Great Britain. Edinburgh: A. \& C. Black.

Zamuner, A.B. \& Falaschi, P. 2005. Agathoxylon matildense n.sp., araucarian wood from the Cerro Madre e Hija petrified forest, La Matilde Formation (Middle Jurassic), Santa Cruz province, Argentina. Ameghiniana 42: 339-346.

Zheng, S.L. 2000. Review of taxonomic and nomenclatural problems on Dadoxylon and Araucarioxylon in recent years. Chin. Bull. Bot. (spec. iss.): 53-60. [in Chinese with English abstract]

Appendix 1. Names and affiliation of the peoples who answered to the poll.

Rajanikanth Annamraju (Birbal Sahni Institute, India), Sidney Ash (University of New Mexico, U.S.A.), Pieter Baas (Leiden University, Netherlands), Marion Bamford (University of the Witwatersrand, South Africa), Richard Bateman (Kew Botanical Gardens, U.K.), Menno Booi (Netherlands Center for Biodiversity Naturalis), Nareerat Boonchai (Research Center of Paleontology and Stratigraphy, Jilin University, China), Mariana Brea (CICYTTP-CONICET, Argentina), Alexandra Crisafulli (UNNE - CECOAL - CONICET, Argentina), Anne-Laure Decombeix (CIRAD, Montpellier), Martina Dolezych (Senckenberg Natural History Collections Dresden Germany), Tânia Dutra (UNISINOS, Brazil), Luis G. Esteban (Universidad Politécnica de Madrid, Spain), Paula Falaschi (Museo de Cs. Naturales, La Plata, Argentina), Howard Falcon-Lang (University of London, U.K.), Zhuo Feng (Yunnan University, China), Silvia Gnaedinger (CECOAL-CONICET, UNNE, Argentina), Margot Guerra Sommer (Universidade Federal do Rio Grande do Sul, Brazil) Melise Harland (Getech, U.K.), Rafael Herbst (CONICET, Argentina), Jason Hilton (University of Birmingham, U.K.), Eugenia Iamandei (Geological Institute of Romania), Stãnilã Iamandei (Geological Institute of Romania), Hong-Hen Jiang (Graduate University of the CAS, China), Zikun Jiang (Nanjing Institute of Geology and Palaeontology, CAS, China), Kyungsik Kim (Chonbuk University, South-Korea), Johanna van Konijnenburg-van Cittert (Utrecht University and Naturalis Biodiversity Center, Leiden, Netherlands), Lutz Kunzmann (Senckenberg Naturhistorische Sammlungen Dresden, Germany), Francine Kurzawe (Universidade Federal do Rio Grande do Sul, Brazil), Stephen McLoughlin (Naturhistoriska Riksmuseet, Stockholm, Sweden), Sheila Merlotti (Universidade Federal de Santa Catarina, Brazil), Brigitte Meyer-Berthaud (Université de Montpellier, France), Serge Naugolnykh (Geological Institute, Moscow, Russia), Harufumi Nishida (Chuo University, Japan), Changhwan Oh (Chonbuk University, South-Korea), Olga Orlova (Moscow State University, Russia), Paloma de Palacios (Universidad Politécnica de Madrid, Spain), Marc Philippe (Université Lyon 1, France), Mike Pole (Queensland Herbarium, Brisbane Botanic Gardens, Australia), Imogen Poole (Aberdeen University, Scotland), Roberto Pujana (Museo Argentino de Ciencias Naturales, Argentina), Ronny Rößler (Museum für Naturkunde, Chemnitz, Germany), Patricia Ryberg (University of Kansas, U.S.A.), Jakub Sakala (Charles University in Prague, Czech Republic), Rodney Savidge (University of New-Brunswick, Canada), Stephan Schultka (Museum für Naturkunde - Leibniz Institute at the Humboldt University Berlin), Herbert Süß (Potsdam, Germany), Edith Taylor (University of Kansas, U.S.A.), Kazuo Terada (Fukui Prefectural Dinosaur Museum, Japan), Frédéric Thévenard (Université Lyon 1, France), Teresa Torres (Universidad de Chile en Santiago, Chile), Ezequiel Vera (Museo Argentino de Ciencias Naturales, Argentina), Elisabeth Wheeler (North Carolina State University, U.S.A.), Xiao-ju Yang (Nanjing Institute of Geology and Palaeontology, CAS, China), Gea Zijlstra (Utrecht University, Netherlands), Shaolin Zheng \& Wu Zhang (Shenyang Institute of Geology, Liaoning, China). 